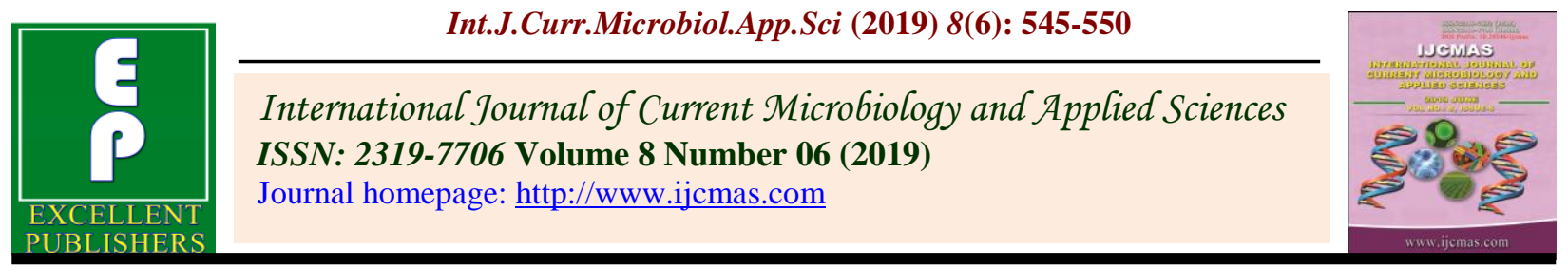

Original Research Article https://doi.org/10.20546/ijcmas.2019.806.063

\title{
Effect of Organic and Inorganic Nutrient Management on Growth Attributes of Rice CV. Co 51
}

\author{
Biswanath Ganguly*, V. Imayavaramban and G. Murugan
}

Department of Agronomy, Faculty of Agriculture, Annamalai University, Tamil Nadu, India

*Corresponding author

A B S T R A C T

Keywords

INM, Organic manure, Growth, Vermicompost

Article Info

Accepted:

07 May 2019

Available Online:

10 June 2019
The field experiments were conducted to evaluate combination of inorganic fertilizers along with organic manures at the Experimental Farm, Department of Agronomy, Annamalai University, Tamil Nadu. The treatments were tested in Split- plot Design and replicated thrice. It was observed that the growth and yield attributes of rice crop viz., plant height, no. of tillers hill ${ }^{-1}$, LAI and dry matter production were favourably influenced by combined application of inorganic fertilizers and organic manures. The effect of application of 125\% NPK + Vermicompost @ $5 \mathrm{t} \mathrm{h}^{-1}+$ Azophos @ $25 \mathrm{~kg} \mathrm{ha}^{-1}+$ Azolla@ $10 \mathrm{~kg} \mathrm{ha}^{-1}+$ Foliar application of Sea weed extract @ $0.2 \%$ at 15 and 30 DAT influenced the growth of rice and recorded highest in all aspects plant height, no. of tillers hill ${ }^{-1}$, LAI and DMP which was on par with the application of $125 \%$ NPK + Vermicompost $5 \mathrm{t} \mathrm{ha}^{-1}+$ Azophos@25 kg ha ${ }^{-1}+$ Azolla @ $10 \mathrm{~kg} \mathrm{ha}^{-1}$.

\section{Introduction}

Rice is grown worldwide including Asia, North and South America, European Union, Middle Eastern and African countries. Rice is the world's most important food for more than half of the world population. Rice is cultivated in 117 countries across the world. More than 90 per cent of the world's rice is grown and consumed in Asia (Seema et al., 2014). Nitrogen is required by plants in the processes of photosynthesis and is involved in the energy reactions in the form of ATP; a key component of chlorophyll, proteins and enzymes and assists the plants in the synthesis and use of carbohydrates (Mengel and Kirkby, 2001; Sara et al., 2013).
Phosphorus plays a crucial role in the root proliferation, consistent grain filling and higher grain yield and quality as well being a constituent of nucleotides such as in ADP and ATP energy bonds and also being involved in many processes such as photosynthesis, mitotic activities, tissue growth and development (Bhattacharyya and Jain, 2000). Potassium is an important plant nutrient and is required in higher amount especially for rice.

Potassium is essential for the maintenance of electrical potential across cellular membranes and cellular turgor enhancing the cell expansion and enlargement, opening and closing of stomata and pollen tube development. It is also involved in activation 
of many enzymes, translocation of nitrate and sucrose (Britto and Kronzucker, 2008).

Vermicompost is a good quality organic fertilizer. Vermicompost is the decomposition product of organic solid waste by earthworms gut and egested as casts (Janagan et al., 2003). Biofertilizers provide eco-friendly organic agro input and are most cost effective than chemical fertilizers (Amudha et al., 2014).

Biofertilizers are living cells of different types of microorganisms (bacteria, fungi and algae) which have an ability to mobilize nutritionally important elements from non-usable form. These microorganisms require organic matter for their growth and activity in soil and provide valuable nutrients to the plant (Saini et al., 2004). Microbiological fertilizers are important to environment friendly and sustainable agricultural practices (Bloemberg et al., 2000). A compost biofertilizer inoculums containing both Azospirillum and Phosphobacteria is known as Azophos. The main advantage of this single biofertilizer containing both " $\mathrm{N}$ " fixer and phosphorus solubilizer and it is less expensive, easy to use and also better efficacy of both organisms in mixed culture.

Seaweeds constitute the most essential live organisms used on a wide scale commercially and the extracts from seaweeds are commonly called as seaweed liquid fertilizer (SWLF) (Bai et al., 2007).

\section{Materials and Methods}

The field experiment was conducted to study the effect of INM on rice at Experimental Farm, Department of Agronomy, Annamalai University with rice Var Co- 51. The research comprised of main plot $\mathrm{M}_{1}: 150 \% \mathrm{NPK}, \mathrm{M}_{2}$ : $125 \%$ NPK, $\mathrm{M}_{3}: 100 \%$ NPK, $\mathrm{M}_{4}: 75 \%$ NPK. Sub-plot: $\mathrm{S}_{1}$ : FYM $12.5 \mathrm{t} \mathrm{ha}^{-1}, \mathrm{~S}_{2}$ : FYM $6.25 \mathrm{t}$ $\mathrm{ha}^{-1}+$ Azophos@ $25 \mathrm{~kg} \mathrm{ha}^{-1}+$ Azolla $10 \mathrm{~kg}$ $\mathrm{ha}^{-1}, \mathrm{~S}_{3}$ : vermicompost $5 \mathrm{t} \mathrm{ha}^{-1}+$ Azophos@ $25 \mathrm{~kg} \mathrm{ha}^{-1}+$ Azolla $10 \mathrm{~kg} \mathrm{ha}^{-1}, \mathrm{~S}_{4}$ : Soil application Humic Acid @ $30 \mathrm{~kg} \mathrm{ha}^{-1}$ at 15, 30 and 45 DAT + Foliar application of Humic Acid @ $0.3 \%$ at 15, 30 and 45 DAT + Azophos@25 kg ha ${ }^{-1}+$ Azolla $10 \mathrm{~kg} \mathrm{ha}^{-1}, \mathrm{~S}_{5}$ : vermicompost $5 \mathrm{t} \mathrm{ha}^{-1}+$ Azophos @ $25 \mathrm{~kg}$ $\mathrm{ha}^{-1}+$ Azolla $10 \mathrm{~kg} \mathrm{ha}^{-1}+$ Foliar application of Seaweed extract @ $0.2 \%$ at 15 and 30 DAT, S : Soil application Humic Acid @30 $\mathrm{kg} \mathrm{ha}{ }^{-1}$ at 15,30 and 45 DAT + Foliar application of Humic Acid @ 0.3\% at 15, 30 and 45 DAT + Azophos@ $25 \mathrm{~kg} \mathrm{ha}^{-1}+$ Azolla $10 \mathrm{~kg} \mathrm{ha}^{-1}+$ Azolla $10 \mathrm{~kg} \mathrm{ha}^{-1}+$ Foliar application of Seaweed extract @0.2\% at 15 and 30 DAT.

\section{Results and Discussion}

\section{Growth parameters}

\section{Plant height}

Rice plant height increased as the crop growth advanced from active tillering and attained maximum at harvesting stage. INM practices exerted marked influence on the plant height at different growth stages. The data on plant height showed significant difference among main as well as sub treatments at all the stages of observations.

The data on rice plant height recorded highest plant height at 30 DAS, 60 DAS and at harvest stage in the both experiment-I and experiment-II. Among the main treatments, $\mathrm{M}_{2}-125 \%$ NPK gave the highest mean plant height of (68.62), (97.27) and (90.48) for Navarai season as well as (66.80), (95.68) and (87.54) for Kuruvai season respectively. The least plant height was recorded in $\mathrm{M}_{4^{-}} 75 \%$ NPK gave lowest plant height at (58.20), (73.01) and (63.87) for experiment-I as well as (56.48), (67.34) and (51.40) for experiment-II respectively. 
Regarding the sub treatments i.e., Vermicompost@5 tha ${ }^{-1}+$ Azophos@25 kg $\mathrm{ha}^{-1}+$ Azolla @10 kg ha ${ }^{-1}+$ foliar application of Sea Weed Extract @ 0.2\% at 15 and 30 DAT $\left(\mathrm{S}_{5}\right)$ recorded the highest plant height of (64.66), (87.91) and (80.21) for experiment-I as well as (62.84), (84.72) and (73.83) for experiment-II respectively, which was on par with Vermicompost@5 t ha ${ }^{-1}+$ Azophos @ $25 \mathrm{~kg} \mathrm{ha}^{-1}+$ Azolla@ $@ 10 \mathrm{~kg} \mathrm{ha}^{-1}\left(\mathrm{~S}_{3}\right)$. The least plant height was obtained with FYM @ $6.25 \mathrm{t} \mathrm{ha}^{-1}+$ Azophos@ $25 \mathrm{~kg} \mathrm{ha}^{-1}+$ Azolla @ $10 \mathrm{~kg} \mathrm{ha}^{-1}\left(\mathrm{~S}_{2}\right)$ the plant height being (62.14), (82.37) and (74.19) for experiment-I as well as (60.43), (78.33) and (64.88) for experiment-II respectively.

There was significant interaction between the inorganic fertilizer and organic manures application on rice for plant height. The treatment combination of $125 \%$ NPK+ Vermicompost@5 tha ${ }^{-1}+$ Azophos@25 kg ha $^{-1}+$ Azolla @10 kg ha ${ }^{-1}+$ foliar application of Sea Weed Extract@ $0.2 \%$ at 15 and 30 DAT $\left(\mathrm{M}_{2} \mathrm{~S}_{5}\right)$ recorded highest plant height of (69.87), (99.98) and (93.48) for experiment-I (67.95), (98.89) and (91.53) for experiment-II respectively. The least plant height of (56.83), (70.22) and (60.87) for experiment-I (55.25),(64.15) and (44.28) for experiment-II respectively, was recorded by the treatment 75\% NPK + FYM @6.25 tha ${ }^{-1}+$ Azophos@ $25 \mathrm{~kg} \mathrm{ha}^{-1}+$ Azolla @ $10 \mathrm{~kg} \mathrm{ha}^{-1}\left(\mathrm{M}_{4} \mathrm{~S}_{2}\right)$.The variation in plant height among nutrients may be ability of different combination of applied nutrients. Combined nutrients application offers readily available nutrients to the plants, this was conformity by Paul et al., (2013).

\section{No. of tillers hill ${ }^{-1}$}

Significant variation in number of tillers hill $^{-1}$ existed due to the INM practices. Among the treatments, $\mathrm{M}_{2}-125 \%$ NPK gave the highest mean tillers hill $^{-1}$ of (18.68), (30.88) and (25.63) for experiment-I as well as (18.30),
(28.51) and (24.76) for experiment-II respectively. The least tillers hill $^{-1}$ was recorded in $\mathrm{M}_{4}-75 \%$ NPK gave lowest tillers hill $^{-1}$ at (12.68), (21.45) and (17.41) for experiment-I as well as (11.42), (18.35) and (15.73) for experiment-II respectively.

Regarding the sub treatments i.e., Vermicompost@5 tha ${ }^{-1}+$ Azophos@ $25 \mathrm{~kg}$ $\mathrm{ha}^{-1}+$ Azolla@10 $\mathrm{kg} \mathrm{ha}^{-1}+$ foliar application of Sea Weed Extract@ $0.2 \%$ at 15 and 30 DAT $\left(\mathrm{S}_{5}\right)$ recorded the highest tillers hill ${ }^{-1}$ of (16.41), (27.27) and (22.53) for experiment-I as well as (15.65), (24.62) and (21.30) for experiment-II respectively, which was on par with Vermicompost @ $5 \mathrm{t} \mathrm{ha}^{-1}+$ Azophos@ $25 \mathrm{~kg} \mathrm{ha}{ }^{-1}+$ Azolla @ $10 \mathrm{~kg} \mathrm{ha}^{-1}\left(\mathrm{~S}_{3}\right)$. The least tillers hill ${ }^{-1}$ at (14.95), (25.06) and (20.54) for experiment-I as well as (13.99), (22.21) and (19.13) for experiment-II respectively, was obtained with application of FYM@6.25 t ha ${ }^{-1}+$ Azophos @ $25 \mathrm{~kg} \mathrm{ha}^{-1}+$ Azolla@10 kg ha ${ }^{-1}\left(\mathrm{~S}_{2}\right)$.

There was significant interaction between the inorganic fertilizer and organic manures application on rice for tiller hill ${ }^{-1}$. The treatment combination of $125 \% \mathrm{NPK}+$ Vermicompost@5 tha ${ }^{-1}+$ Azophos@25 kg $\mathrm{ha}^{-1}+$ Azolla@10 $\mathrm{kg} \mathrm{ha}^{-1}+$ foliar application of Sea Weed Extract @ 0.2\% at 15 and 30 $\left(\mathrm{M}_{2} \mathrm{~S}_{5}\right)$ recorded highest tillers hill ${ }^{-1}$ of (19.37), (31.96) and (26.59) for experiment-I as well as (19.11), (29.69) and (25.88) for experiment-II. The least tillers hill ${ }^{-1}$ of (11.87), (20.37) and (16.32) for experiment-I as well as (10.59), (17.12) and (14.59) for experiment-II respectively, was recorded by the treatment 75\% NPK + FYM @6.25 t ha ${ }^{-1}$ +Azophos@25 kg ha ${ }^{-1}+$ Azolla@10 kg $\mathrm{ha}^{-1}\left(\mathrm{M}_{4} \mathrm{~S}_{2}\right)$. The variation in no. of tillers hill ${ }^{-}$ ${ }^{1}$ among nutrients may be ability of different combination of applied nutrients. Highest no. of tillers hill $^{-1}$ is found due to application of combined rate of nutrients (Mirza et al., 2010). 


\section{LAI}

Noteworthy difference among main and sub treatments was observed on leaf area index at flowering stages.

Between certain main treatments, the highest LAI of Navarai and Kuruvai was obtained with $\mathrm{M}_{2}-125 \%$ NPK gave the highest mean LAI of (5.28), (6.62) and (6.37) for experiment-I as well as of (5.18), (6.07) and (6.06) for experiment-II respectively. The least LAI was recorded in $\mathrm{M}_{4-}-75 \%$ NPK gave lowest LAI of (2.81), (3.61) and (3.41) for experiment-I as well as of (2.31), (2.90) and (2.75) for experiment-II respectively.

Regarding the sub treatments i.e., Vermicompost@ $5 \mathrm{t} \mathrm{ha}^{-1}+$ Azophos@ $25 \mathrm{~kg}$ ha $^{-1}+$ Azolla @10 kg ha ${ }^{-1}+$ foliar application of Sea Weed Extract@ $0.2 \%$ at 15 and 30 DAT $\left(\mathrm{S}_{5}\right)$ recorded the highest LAI (4.41), (5.52) and (5.26) for experiment-I as well as (4.10), (4.89) and (4.84) for experiment-II, which was with on par with Vermicompost @ 5 t ha $^{-1}+$ Azophos@25 kg ha ${ }^{-1}+$ Azolla@ $10 \mathrm{~kg} \mathrm{ha}^{-1}\left(\mathrm{~S}_{3}\right)$. The least LAI (2.44), (4.75) and (4.51) for experiment-I as well as (3.40), (4.09) and (4.01) for experiment-II respectively, was obtained with FYM @6.25 tha ${ }^{-1}+$ Azophos@25 kg ha ${ }^{-1}+$ Azolla@10 $\mathrm{kg} \mathrm{ha}^{-1}\left(\mathrm{~S}_{2}\right)$.

There was significant interaction between the inorganic fertilizer and organic manures application on rice for LAI. The treatment combination of $125 \% \mathrm{NPK}+$ Vermicompost @ $5 \mathrm{t} \mathrm{ha}^{-1}+$ Azophos@ $25 \mathrm{~kg} \mathrm{ha}^{-1}+$ Azolla @ $10 \mathrm{~kg} \mathrm{ha}^{-1}+$ foliar application of Sea Weed Extract@0.2\% at 15 and 30 DAT $\left(\mathrm{M}_{2} \mathrm{~S}_{5}\right)$ recorded highest LAI (5.63), (6.99) and (6.72) for experiment-I as well as (5.51), (6.49) and (6.43) for experiment-II respectively. The least LAI (2.44), (3.21) and (3.02) for experiment-I as well as (1.99), (2.47) and (2.39) for experiment-II respectively, was obtained with FYM @ $6.25 \mathrm{t} \mathrm{ha}^{-1}+$ Azophos @ $25 \mathrm{~kg} \mathrm{ha}^{-1}+$ Azolla @ $10 \mathrm{~kg} \mathrm{ha}^{-1}\left(\mathrm{M}_{4} \mathrm{~S}_{2}\right)$. Higher LAI is due adequate application of Integration nutrients directly and relatively affect on crop growth response in photosynthesis Pandian et al., (2005).

\section{DMP}

The data on dry matter production (DMP) of rice recorded at harvest stage in Navarai and Kuruvai seasons. INM application exhibited significant differences on DMP at harvest stage in both season. Among the treatments, $\mathrm{M}_{2^{-}}{ }^{125 \%}$ NPK gave the highest mean DMP of (13306.50) of for Navarai season as well as (12977.83) for Kuruvai season respectively. The least DMP was recorded in $\mathrm{M}_{4^{-}} 75 \%$ NPK gave lowest DMP of (7882.16) for experiment-I as well as (6827.66) for experiment-II respectively.

Regarding the sub treatments i.e., Vermicompost@5 tha ${ }^{-1}+$ Azophos@ $25 \mathrm{~kg}$ $\mathrm{ha}^{-1}+$ Azolla@10 kg ha ${ }^{-1}+$ foliar application of Sea Weed Extract @ 0.2\% at 15 and 30 DAT $\left(\mathrm{S}_{5}\right)$ recorded the highest DMP of (11322.25) for experiment-I as well as (10745.50) for experiment-II respectively, which was on par with Vermicompost @ $5 \mathrm{t}$ $\mathrm{ha}^{-1}+$ Azophos@25 kg ha ${ }^{-1}+$ Azolla@10 $\mathrm{kg} \mathrm{ha}^{-1}\left(\mathrm{~S}_{3}\right)$. The least DMP of (9898.25) for experiment-I as well as (9132.25) for experiment-II respectively, was obtained with FYM@6.25 t ha ${ }^{-1}+$ Azophos@ $25 \mathrm{~kg} \mathrm{ha}^{-1}+$ Azolla@10 kg ha ${ }^{-1}\left(\mathrm{~S}_{2}\right)$.

There was significant interaction between the inorganic fertilizer and organic manures application on rice for DMP. The treatment combination of $125 \% \mathrm{NPK}+$ Vermicompost @ $5 \mathrm{t} \mathrm{ha}^{-1}+$ Azophos@ $25 \mathrm{~kg} \mathrm{ha}^{-1}+$ Azolla @ $10 \mathrm{~kg} \mathrm{ha}^{-1}+$ foliar application of Sea Weed Extract@0.2\% at 15 and 30 DAT $\left(\mathrm{M}_{2} \mathrm{~S}_{5}\right)$ recorded DMP of (14120) for experiment-I (13711) for experiment-II respectively. The 
least DMP of (7149) for experiment-I (5854) for experiment-II respectively, was recorded by the treatment 75\% NPK + FYM @6.25 t $\mathrm{ha}^{-1}+$ Azophos@25 kg ha ${ }^{-1}+$ Azolla@10 $\mathrm{kg} \mathrm{ha}^{-1}\left(\mathrm{M}_{4} \mathrm{~S}_{2}\right)$. The variation in DMP among nutrients may be ability of different combination of applied nutrients. Higher DMP accumulation might be due associated significantly and positively with plant height. The present study of findings is agreed with (Krishnaprabu and Grace, 2017).

In conclusion, trials were found that plant height, no. of tillers hill $^{-1}$ highest for application of $\left(125 \%+\right.$ vermicompost $5 \mathrm{t} \mathrm{ha}^{-1}$ +Azophos@25 kg ha ${ }^{-1}+$ Azolla@10 kg $\mathrm{ha}^{-1}+$ Foliar application of Seaweed extract @ $0.2 \%$ at 15 and 30 DAT) combined nutrients management at field level with it not only increases production simultaneously increases productivity. At the same time it reflects on LAI and DMP at higher extend.

\section{References}

Amudha, R., S. Karunakaran, S. Dhanasekaran, K. Hemalatha, R Monika Shanmugapriya, T. Pand Sornolatha. 2014. Isolation and mass production of biofertilizers (Azotobactor and Phosphobacter). International Journal of Latest Research and Technology, 3: p. 79-81.

Bai, N.R., N. R. L. Banu, J. W. Prakash, and S. J. Goldi. 2007. Effects of Asparagopsistaxi formis extract on the growth and yield of (Phaseolus aureus). J. Basic Appl. Biol., 1(1): 611.

Bhattacharyya, P. and R.K. Jain. 2000. Phosphorus solubilizing biofertilizers in the whirlpool of rock phosphatechallenges and opportunities. Fert. News., 45: 45-51.

Bloemberg, G.V., A.H.M. Wijifijes, G.E.M. Lamers, N. Stuurman and B.J.J.
Lugtenberg. 2000. Simultaneous imaging of Pseudomonas fluorescence WCS 3655 populations expressing three different auto fluorescent proteins in rhizosphere: new perspective for studying microbial communities. Mol. Plant Mic. Int., 13: 1170-1176.

Britto, D.T. and H.J. Kronzucker. 2008. Cellular mechanisms of potassium transport in plants. Physiol. Plant, 133: 637-650.

Janagan, K. V. Sathish, and A. Vijaykumar. 2003. A sustainable system for solid waste treatment-Vermiculture Di dalam: Bunch MJ, Suresh VM, Kumaran TV (ed). Proceedings of the third international Conference on Environment and Health, Chennai, India, 15-17 December, 2003. Chennai: Department of Geography, University of Madras and Faculty of Environmental studies, York University. Pp: 175-185.

Krishnaprabu, N., and T. Myrtle Grace. 2017. Effect of nutrient management on growth and yield of traditional red rice land races (Oryza sativa L.). IJCS, 5(6): 180-186.

Mengel, K. and E. A. Kirkby. 2001. Boron: In principles of plant nutrition, 5 th ed. Kluwer Academic Publishers ( $5^{\text {th }}$ ed.) Dordrecht, Boston, London, Netherlands.

Mirza, Hasanuzzaman, K.U., N.M. Ahamed, N. Rahmatullah, K.N. Akhterand and M.L. Rahman.2010. Plant growth characters and productivity of wetland rice (Oryza sativa L.) as affected by application of different manures. Emir. J. food Agric. 22(1): 46-58.

Pandian, B.J., D. Jawahar, S.K. Natarajan, R. Nagarajan and S. Krishnakumar. 2005. NPK fertilizers for hybrid rice (Oryza sativa L.) productivity in alfisols of southern districts of Tamil Nadu. 
Asian Journal of Plant Sciences, 4(6): 574-576.

Paul, P.S. Bisht, P.C. Pandey, D.K. Singh and S. Roy. 2013. Rice productivity and soil fertility as influenced by nutrient management in rice (Oryza sativa $\mathrm{L}$.)wheat (Triticum aestivum) cropping system. Indian J. Agron., 58 (4): 495499.

Saini, V., R. Berwal, J. Sharma and A. Singh. 2004. Biofertilizers: current status and perspectives in agriculture. Poll. Res., 23(4): 665-676.
Sara, S., M. Morad and C.M. Reza. 2013. Effects of seed inoculation by Rhizobium strains on chlorophyll content and protein percentage in common bean cultivars (Phaseolus vulgaris L.). Intl. J. Biosci., 3: 1-8.

Seema, M., M. Krishna and T.T. Devi. 2014. Effect of nitrogen and weed management on nutrient uptake by weeds under direct seeded aerobic rice. An. Inter. Quality J. Life Sci., 9(2): 535-537.

\section{How to cite this article:}

Biswanath Ganguly, V. Imayavaramban and Murugan, G. 2019. Effect of Organic and Inorganic Nutrient Management on Growth Attributes of Rice CV. Co 51. Int.J.Curr.Microbiol.App.Sci. 8(06): 545-550. doi: https://doi.org/10.20546/ijcmas.2019.806.063 